\title{
相間リアクトル付きサイリス夕整流回路の 電流バランスについて
}

$\begin{array}{lllll}\text { 正員 } & \text { 中 } & \text { 俊 } & \text { 彦 } & \text { (釧路高専) } \\ \text { 正員 小笠原 } & \text { 悟 } & \text { 司 } & \text { (長岡技科大) } \\ \text { 正員 } & \text { 赤 木 } & \text { 泰 } & \text { 文 } & \text { (長岡技科大) } \\ \text { 正員 難波江 } & & \text { 章 } & \text { (長岡技科大) }\end{array}$

\section{On the Current Balance of Phase-Controlled Thyristor Converter having Interphase Reactors}

Toshihiko Tanaka, Member (Kushiro Technical College), Satoshi Ogasawara, Member, Hirofumi Akagi, Member, Akira Nabae, Member (Nagaoka University of Technology)

A parallel connected thyristor converter with an interphase reactor has been used widely as a low voltage high current $\mathrm{DC}$ power supply because of high efficiency, compared with a series one. It seems to be the most suitable for superconducting magnetic energy storage systems in particular. If the parallel converter consisting of two thyristor converters is operated under different firing angles in the two due to imperfect adjustment in the control circuit or something like that, unbalance may occur in the output DC current of each converter.

The purpose of this paper is to discuss the current unbalance of a parallel thyristor converter in detail. The main points are summarized as follows:

(1) It is clarified theoretically that the unbalance of DC output current may occur even when the difference of firing angles is less than $1^{\circ}$.

(2) It is verified experimentally that the proposed simple current feedback makes it possible to balance the DC output current of the parallel thyristor converter.

(3) An interphase reactor without gap is able to take the place of a conventional interphase reactor with gap which is used widely. Compared with the conventional one, the volume of the interphase reactor without gap is much small.

キーワード：相間リアクトル，サイリスタ整流回路，電流バランス，電流フィードバック

\section{1.まえがき}

低電圧・大電流の直流電源の用途としては，相間リ アクトルを有する並列接続形サイリス夕整流回路が広 く使用されている。これは, 直列接続形サイリス夕整 流回路に比較し効率が高く, 特に系統安定化装置ある いは核融合炉用パルス電源などとして実用化が期待さ れている超電導エネルギー眝蔵システムの電力変換器 に適している。これら大容量の整流回路では力率の改
善および高調波電流の低減が必要であり,このため多 数台のサイリスタブリッジを並列接続した各種の回路 構成が提案されている(1) (3)。

一般に, 相間りアクトル付きサイリスタ整流回路 は, 2 台の整流回路に $30^{\circ}$ の位相差を有する三相電源 を接続して 12 相整流回路として動作する。この場合， 相間リアクトルは各整流回路の出力電圧差を吸収する リアクトルとして動作すると共に, 各整流回路の出力 電流の平均值を等しくするバランサとしても動作する 
重要な役割を果たしている。このような相間リアクト ルの基本的な考え方扔よび機能については，水銀整流 器の時代加ら数多く検討されている。しかし, 何らか の原因で整流回路の制御角に誤差を生じた場合，各整 流回路の出力電流の平均值がアンバランスとなること が知られているが(4)，これらの現象について詳細に解 析した例は，著者らの知る限り報告されていないよう に思われる。

本論文は，相間リアクトル付きサイリスタ整流回路 の出力電流バランスについて検討したものである。ま ず,サイリスタの転流期間中でも各整流回路の出力電 流が一定という仮定が成立しない点を考慮して整流回 路の出力電流のアンバランスを与える解析式を導出 し，それそれの整流回路の制御角の誤差が比較的小さ な場合でも整流回路の出力電流の平均值がアンバラン スとなることを理論的に明らかにする。次に，この対 策として出力電流の差を検出してフィードバックする ことが，どの程度有効であるかを定量的に明らかにす る。従来, 出力電流がアンバランスとなった状態でも 各整流回路の出力電圧差を吸収するために，ギャップ を有する大型の相間リアクトルが用いられている。し かし，電流フィードバックを付加することにより，相 間リアクトルは出力電圧差を吸収する機能のみに着目 して設計することが可能であり，このため相間リアク トルにギャップのない $300 \mathrm{~Hz}$ の相間変圧器を用いる ことができる。相間変圧器は相間リアクトルに比べ, 鉄心が飽和しない状態では非常に大きなリアクトルと して動作する。このため，従来の相間リアクトルと比 較して大幅な小形・軽量化が可能である。この点につ いても，詳細に検討する。

\section{2. 出力電流のアンバランスの解析}

〈2・1〉解析を行ううえでの仮定 図 1 は相間り アクトル付並列接続形サイリス夕整流回路の基本的 な構成図である。ここで，解析を行うにあたり以下の 仮定をおく。

（1）負荷には十分に大きな平滑リアクトルを有す るものとし $I_{d}=$ 一定とする。

（2）サイリス夕の順方向降下, 変圧器・相間リア クトルの巻線抵抗などは無視する。

一般に, 整流回路の重なり角などの解析では, 整流 回路の出力電流（図 1 では $i_{d 1}, i_{d 2}$ ) が転流期間中一 定という条件の下で解析が行われている。しかし, 本 解析では転流期間中において図10 $I_{d}\left(=i_{d 1}+i_{d 2}\right)$ は 一定であるが, それぞれの整流回路の出力電流 $i_{d 1}$, $i_{d 2}$ は一定という仮定が成立しないことを考慮して解

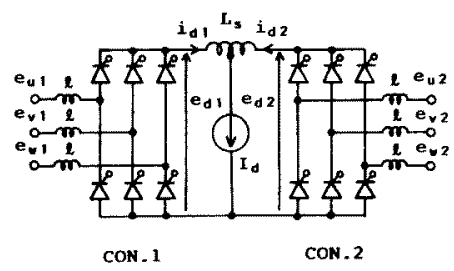

図 1 回路構成

Fig. 1. Circuit configuration.

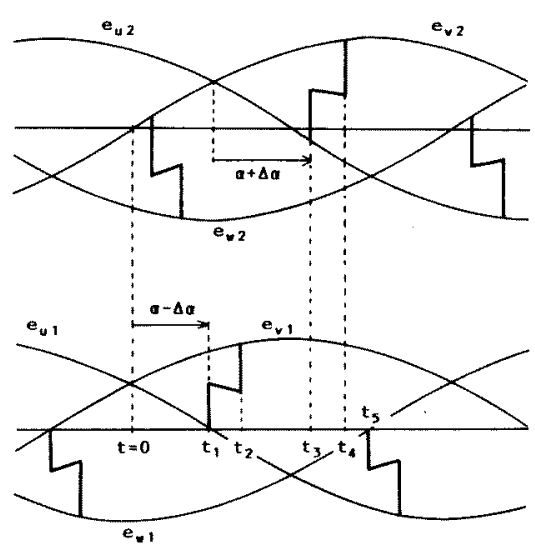

図 2 整流回路出力波形

Fig. 2. Output waveforms of thyristor converter.

析を行う。

〈2・2〉 基本式の導出 図 2 に整流回路の出力波 形を示す。ここで，

$$
\begin{aligned}
& e_{u 1}=\frac{\sqrt{2}}{\sqrt{3}} E_{1} \sin \left(\omega t+\frac{5}{6} \pi\right) \\
& e_{v 1}=\frac{\sqrt{2}}{\sqrt{3}} E_{1} \sin \left(\omega t+\frac{\pi}{6}\right) \cdots \\
& e_{w 1}=\frac{\sqrt{2}}{\sqrt{3}} E_{1} \sin \left(\omega t-\frac{\pi}{2}\right) \cdots \\
& e_{u 2}=\frac{\sqrt{2}}{\sqrt{3}} E_{2} \sin \left(\omega t+\frac{2}{3} \pi\right) \\
& e_{v 2}=\frac{\sqrt{2}}{\sqrt{3}} E_{2} \sin \omega t \cdots \cdots \cdots \cdots \\
& e_{w 2}=\frac{\sqrt{2}}{\sqrt{3}} E_{2} \sin \left(\omega t-\frac{2}{3} \pi\right)
\end{aligned}
$$

ただし， $E_{1} ， E_{2}$ :それぞれの整流回路の線 間電圧実効值

である。

CON.1は $\alpha-\Delta \alpha$, CON.2は $\alpha+\Delta \alpha$ でそれぞれ点 弧され，2台の整流回路の制御角の誤差は $2 \Delta \alpha$ とす 


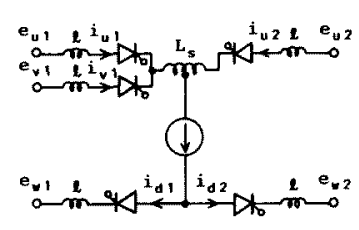

図 $3 t_{1} \leqq t \leqq t_{2}$ 等価回路

Fig. 3. Equivalent circuit for $t_{1} \leqq t \leqq t_{2}$.

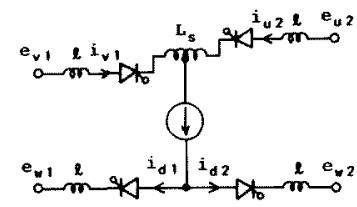

図 $4 t_{2} \leqq t \leqq t_{3}$ 等価回路

Fig. 4. Equivalent circuit for $t_{2} \leqq t \leqq t_{3}$.

る。このとき, 解析の対象となるモードは四種類と なる。

(1) $t_{1} \leqq t<t_{2} \quad$ 図 3 はこのモードの等価回路で ある。時刻 $t_{1}, t_{2}$ の電気角をそれぞれ $\alpha-\Delta \alpha, \alpha-\Delta \alpha$ $+u_{1}$ とすると, このモードの CON.10出力電流の 增加量 $\Delta i_{d 1}$ は次式で与えられる（導出については付 録 1 参照)。

$$
\begin{aligned}
\Delta i_{d 1}= & \frac{\sqrt{6} E_{1}-\sqrt{8} E_{2}}{\omega\left(4 L_{s}+7 l\right)}\left\{\sin \left(\alpha-\Delta \alpha+u_{1}\right)\right. \\
& -\sin (\alpha-\Delta \alpha)\} \quad \ldots \ldots \ldots \ldots \ldots \ldots \ldots \ldots \ldots
\end{aligned}
$$

ただし， $L_{s}$ : 相間りアクトルの両端のイン

ダクタンス, l: 転流インダクタンス

ここで, 重なり角 $u_{1}$ は次式となる（導出については 付録 2 参照)。

$$
\begin{aligned}
u_{1}= & \cos ^{-1}\left\{\cos \left(\alpha-\Delta \alpha-\phi_{1}\right)-\frac{i_{d 1}\left(t_{1}\right)}{K_{3}}\right\} \\
& -\left(\alpha-\Delta \alpha-\phi_{1}\right)
\end{aligned}
$$

たたし，

$$
\begin{aligned}
& K_{3}=\sqrt{K_{1}^{2}+K_{2}^{2}}, \quad \phi_{1}=\tan ^{-1} \frac{K_{2}}{K_{1}} \\
& K_{1}=\frac{\sqrt{2} E_{1}}{2 \omega l}, \quad K_{2}=\frac{\sqrt{6} E_{1}-\sqrt{8} E_{2}}{2 \omega\left(4 L_{s}+7 l\right)}
\end{aligned}
$$

(2) $t_{2} \leqq t<t_{3}$ 図 4 にこのモードの等洒回路を 示す。時刻 $t_{3}$ の電気角を $\alpha+\Delta \alpha+(\pi / 6)$ とすると, $\Delta i_{d 1}$ 位次式となる。

$$
\begin{aligned}
\Delta i_{d 1}= & \frac{\sqrt{2}}{2 \omega\left(L_{s}+2 \ell\right)}\left[E _ { 1 } \left\{\cos \left(\alpha-\Delta \alpha+u_{1}+\frac{\pi}{3}\right)\right.\right. \\
& +\sin (\alpha+\Delta \alpha)\}-E_{2}\left\{\sin \left(\alpha+\Delta \alpha+\frac{\pi}{6}\right)\right. \\
& \left.\left.-\sin \left(\alpha-\Delta \alpha+u_{1}\right)\right\}\right] \cdots \cdots \cdots \cdots(8)
\end{aligned}
$$

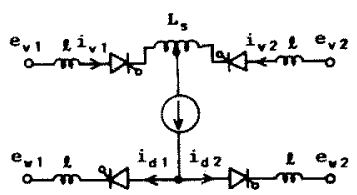

図 $5 t_{3} \leqq t \leqq t_{4}$ O等価回路

Fig. 5. Equivalent circuit for $t_{3} \leqq t \leqq t_{4}$.

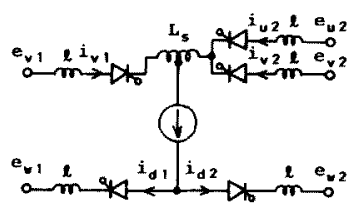

図 $6 \quad t_{4} \leqq t \leqq t_{5}$ の等価回路

Fig. 6. Equivalent circuit for $t_{4} \leqq t \leqq t_{5}$.

(3) $t_{3} \leqq t<t_{4}$ 図 5 はこのモードの等価回路を 示したものである。重なり角を $u_{2}$ とすると時刻 電気角は $\alpha+\Delta \alpha+(\pi / 6) u_{2}$ となり， $\Delta i_{\alpha 1}$ は次式と なる。

$$
\begin{aligned}
& \Delta i_{d 1}=\frac{\sqrt{8} E_{1}-\sqrt{6} E_{2}}{\omega\left(4 L_{s}+7 l\right)}\left\{\sin \left(\alpha+\Delta \alpha+u_{2}\right)\right. \\
& -\sin (\alpha+\Delta \alpha)\}
\end{aligned}
$$

ここで，衫は次式で与えられる。

$$
\begin{aligned}
u_{2}= & \cos ^{-1}\left\{\cos \left(\alpha+\Delta \alpha-\phi_{2}\right)-\frac{i_{d 2}\left(t_{3}\right)}{N_{3}}\right\} \\
& -\left(\alpha+\Delta \alpha-\phi_{2}\right)
\end{aligned}
$$

ただし，

$$
\begin{aligned}
& N_{3}=\sqrt{N_{1}^{2}+N_{2}^{2}}, \quad \phi_{2}=\tan ^{-1}-\frac{N_{2}}{N_{1}} \\
& N_{1}=\frac{\sqrt{2} E_{1}}{2 \omega l}, \quad N_{2}=\frac{\sqrt{8} E_{1}-\sqrt{6} E_{2}}{2 \omega\left(4 L_{s}+7 l\right)}
\end{aligned}
$$

(4) $t_{4} \leqq t<t_{5}$ 図 6 にこのモードの等価回路を 示す。時刻 $t_{5}$ 電気角は， $\alpha-\Delta \alpha+(\pi / 3)$ であるか ら, $\Delta i_{d 1}$ は次式で与えられる。

$$
\begin{aligned}
\Delta i_{d 1}= & \frac{\sqrt{2}}{2 \omega\left(L_{s}+2 l\right)}\left[E _ { 1 } \left\{\sin \left(\alpha-\Delta \alpha+\frac{\pi}{6}\right)\right.\right. \\
& \left.-\sin \left(\alpha+\Delta \alpha+u_{2}\right)\right\}-E_{2}\{\sin (\alpha-\Delta \alpha) \\
& \left.\left.+\cos \left(\alpha+\Delta \alpha+u_{2}+\frac{\pi}{3}\right)\right\}\right]
\end{aligned}
$$

従って，2台の整流回路がそれぞれ一度の転流を行 うことによる CON.10出力電流の平均值の増加分 $\Delta I_{d 1}$ は，(7)〜(10)式の和で与えられる。

〈2・3〉解析式による計算結果 前節で導出した 


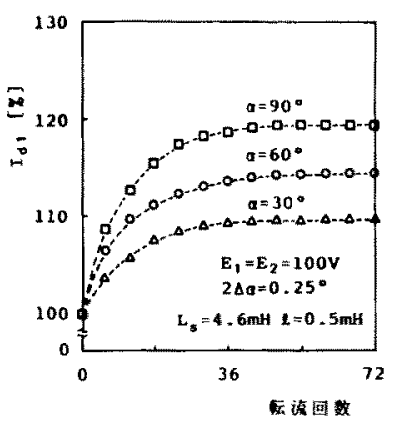

図 $7 L_{s}=$ 一定の場合の計算結果

Fig. 7. Calculated results under $L_{s}=$ constant.

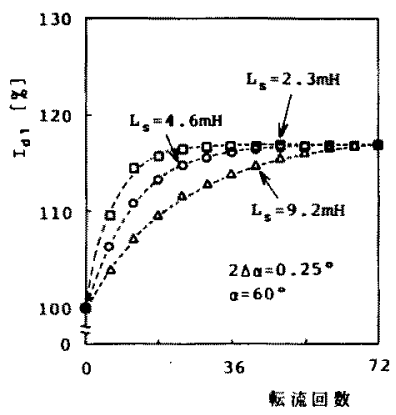

図 $8 L_{s}$ を変化した場合の計算結果

Fig. 8. Calculated results as a parameter $L_{s}$.

解析式から出力電流のパランスについて計算した結果 を以下に示す。2 台の整流回路の制御角 $\alpha$ が等しく各 整流回路の出力電流の平均值 $I_{d 1}, I_{d 2}$ が完全にバラン スした状態で制御角に誤差を与え，その後の転流回数 と整流回路の出力電流の平均值 $I_{d 1}$ との関係を求め た。また, $I_{d} / 2$ を, 綐軸 $I_{d 1}$ の $100 \%$ としている。

図 7 は相間りアクトル $L_{s}=4.6 \mathrm{mH}(=25 \%, 50 \mathrm{~Hz}$ $100 \mathrm{~V} 10 \mathrm{~A}$ ベース)一定で電源電圧が等しいときに制 御角が $0.25^{\circ}$ の誤差を生じた場合の, 転流回数と $I_{d 1}$ との関係を求めたものである。転流回数が，36回 (120 ms) で定常状態に近づいている。また，制御角 $\alpha=60^{\circ}$ では $I_{d 1}$ の最終值が $110 \%$ を超えている。図 8 は，図７と同じ条件の下で相間リアクトル $L_{s}$ を変化 したときの応答を求めたものである。相間リアクトル $L_{s}$ は， $I_{d 1}$ の定常值に達するまての時間には関倸して いるが $I_{a 1}$ の定常值にはほとんど関倸していない。図 9 は電源電圧が $0.2 \%$ かつ制御角が $0.25^{\circ}$ 翼なったと きの結果を示したものである。図 7 と同様に，転流回 数が 36 回で定常状態に近づいている。一方, 図 10 は

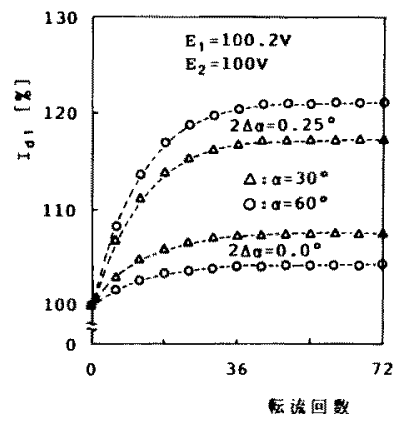

図 $9 E_{1} \neq E_{2}$ の場合の計算結果

Fig. 9. Calculated results under $E_{1} \neq E_{2}$.

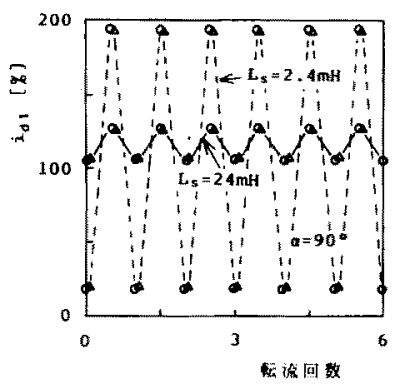

図 $10 \quad i_{d 1}$ の瞬時值

Fig. 10. Instantaneous value of $i_{d 1}$.

Lsを変化したときの $i_{d 1}$ の瞬時值をプロットしたも のである。相間リアクトル $L_{s}$ は $i_{d 1}$ のピーク值に密 接に関係しているが，平均值には関係していない。図 7〜図100計算結果加ら，従来，相間リアクトルには 安全上からギャップを有する大形のものが用いられて いるが、これは整流回路の出力電流がアンバランスと なった場合においてもピーク值を㧕制することを目的 としたものであることがわかる。このとき, 出力電流 の平均値を等しくするために流，電流フィードバック など何らかの対策が必要である。

また，以上の解析ではサイリスタの順方向降下電圧 を無視したが，順方向降下電王は，各整流回路の出力 電流のアンバランスおよびリプルを抑制するように動 作する。促って，水銀整流器などのように順方向降下 電圧を無視できない素子を用いた場合には出力電流の アンバランスおよびリブルは, 本計算結果と比心゙小き くなる。

\section{3. 相間リアクトルの検討}

本章では，〈2・3〉節で得られた結果をもとに相間り アクトルの容量などについて検討する。 
〈3・1〉 ギャップのない場合＼cjkstart図 2 に示した整流 回路の出力電圧波形において，相間りアクトルの両端 の電圧の時間積分を計算することで相間変圧器の最大 磁束密度が算定できる。ここで，簡単のために重なり 角を無視するものとする。

相間リアクトルの鉄心中の磁束を $\phi$ とすると次式 が成立する。

$$
\begin{aligned}
& \phi=\frac{1}{N} \int_{0}^{t} e_{L} d t+\phi_{0} \\
& \text { ただし， } \phi_{0}: t=0 \text { に扔ける磁束 }
\end{aligned}
$$

図 2 において，(1)〜 (6)式から相間リアクトルの両 端の電圧 $e_{L}$ を求め(11)式に代入し整理すると, 鉄心 の最大磁束 $\Phi_{m}$ は次式で与えられる。

$$
\begin{aligned}
\Phi_{m} & =\frac{A_{1} E}{2 \omega N} \int_{\alpha-(\pi / 6)}^{\alpha} \sin \left(\theta+\frac{\pi}{12}\right) d \theta \\
& \fallingdotseq \frac{0.804 \times E \sin \alpha}{4.44 \times 6 \times f N} \ldots \ldots \ldots \ldots \ldots \ldots
\end{aligned}
$$

ただし，

$$
E=E_{1}=E_{2}, \quad A_{1}=\sqrt{2} \sqrt{2-\sqrt{3}}
$$

(12)式から，鉄心の磁束は $\alpha=90^{\circ}$ のときに最大とな ることがわかる。ここで, 重なり角を考慮した場合, （12）式の積分值は重なり角を無視した場合に比べ小さ くなる。従って，重なり角を無視した(12)式による計 算結果は相間変圧器の定格の上限值を与えるものと考 えられる。ここで，電源電圧 $E_{1}=E_{2}=100 \mathrm{~V}$, 電源 周波数 $50 \mathrm{~Hz}$ で鉄心材料にアモルファス鉄心を用い るものとすれば，相間リアクトルとして鉄心が飽和し ないためには図 11 のうう変压器となる。このとき， 鉄心の飽和磁束密度 $B_{m}=0.85 \mathrm{~T}$, 巻数 $N_{1}=42$ 回, 鉄心の有効断面積 $S=8.4 \mathrm{~cm}^{2}$ である。

〈3・2〉 ギャップを有する場合 図11で得られた 変圧器にギャップを付加した場合, どの程度のインダ クタンスが得られるかを検討する。ここで,

（1）鉄心の磁気抵抗を無視する

（2）飽和電流を $10 \mathrm{~A}$ とする

という条件を招く。

一般に，飽和電流を $I_{p}$ とすればギャップの長さ $l_{g}$

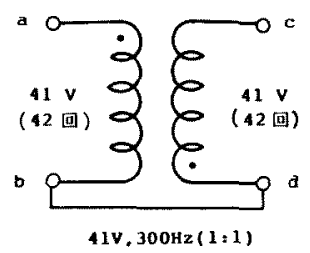

図 11 相間変圧器

Fig. 11. The interphase transformer.
は，次式となる。

$$
l_{g} \fallingdotseq \frac{\mu_{0} N I_{p}}{B_{m}}
$$

また，このときのンダクタンス $L$ は，次式となる。

$$
L \doteqdot \frac{\mu_{0} S N^{2}}{l_{g}}
$$

図 11 の変圧器で計算すると, 条件 (2)よりギャッカ の長 $l_{s}=1.4 \mathrm{~mm}$ が得られ,このときのインダクタン スの大きさ $L$ は $5 \mathrm{mH}(a-c$ 間 $)$ となる。また, 一 次側, 二次側の巻数をそれぞれ半分とし, 電圧定格を $20 \mathrm{~V}$ とした場合にはこれと同様に $l_{s}=0.7 \mathrm{~mm}$ が得 られ，L=2.4 $\mathrm{mH}$ となる。先に示した図 10 は,こ のときの計算結果を示したものである。これと比较 し, ギャップのない変圧器は鉄心が飽和しない籍囲て は非常に大きなインダタタンスとして動作する。この ために，出力電流のリプルを大幅に隇少することが可 能である。従って, 電流フィードバックにより常に出 力電流がバランスした状態を保つことができれば，相 間リアクトルとしてギャップのない変圧器を用いるこ とができる。その結果, 相間リアクトルの小形・軽量 化が可能でる。

\section{4. 実験結果}

$\langle 4 \cdot 1\rangle$ 実験装置の構成 図 12 に実験に用いた整 流回路の構成図を示す。各整流回路はそれぞれ $\Delta-\Delta$ 結線と $\triangle-Y$ 結線の三相変圧器を介して電源と接続き れており，2台の整流回路を相間リアクトルにより並 列接続することで 12 パルス構成としている。ここて， 変珐器の漏れインダクタンスは $0.5 \mathrm{mH}(=2.7 \%$,

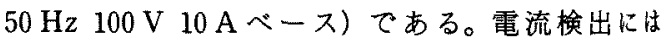
DCCT を使用し，同一のコア上に各整流回路の出力 電流が逆方向となるように電線を巻き，1個のCTて 出力電流の差を検出している。この出力電流の差を PI コントローラを通じて增幅し本来の制御角の指令

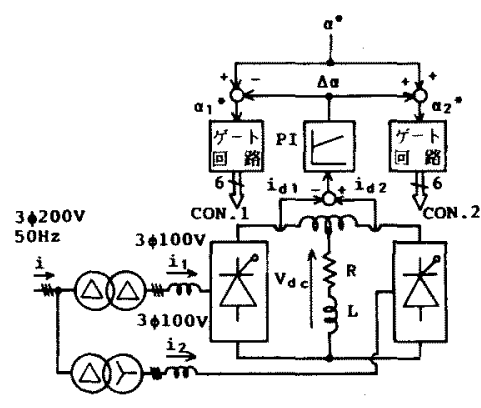

図 12 実験装置構成図

Fig. 12. Block diagram of experimental system. 
值 $\alpha^{*}$ に加算または減算を行ってそれぞれの整流回路 の制御角 $\alpha_{1}, \alpha_{2}$ としている。ここで,サイリス夕整 流回路は余弦制御法を用いているために線形堌幅器と 考えることができ PI コントローラのゲインを容易に 決定することができる。なお，今回実験に用いた PI コントローラのゲインは, 比例定数 $P=6$, 積分時定 数 $T_{i}=2.2 \mathrm{~ms}$ とした。整流回路の負荷は, 負荷電流 I cc を一定とするためにサイリス夕の転流周期に比べ 十分に大きな時定数を有する必要があり, $\tau=120 \mathrm{~ms}$ 程度の $R-L$ 負荷とした。

〈4.2〉実験結果図 13〜図 15 は, 整流回路の 制御角 $\alpha^{*}=60^{\circ}$ (一定) とした場合に電流フィードバ
ックにより各整流回路の出力電流がバランスした状態 で，電流フィードバックを切離したときの応答を求め たものである。比較のために，三種類の相間リアクト ルについて夷験を行った。

図13は相間りアクトルとしてケイ素鋼板を鉄心と する変圧器を用いた場合の応答波形である。（a）図は $20 \mathrm{~V}, 300 \mathrm{~Hz}$ 定格の相間変圧器を用いたもので, 変 圧器の電圧定格が低く出力電流がバランスした状態で も鉄心が飽和するために，整流回路の入力電流にりプ ルを生じている。一方，(b)図は，40 V, $300 \mathrm{~Hz}$ 定 格の相間変圧器を用いた場合であり，良好な特性が得 られている。電流フィードバックが切離された後は，

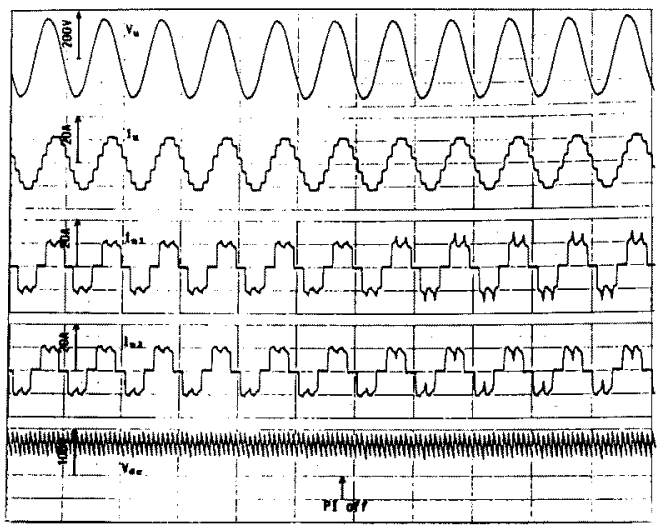

(a) $20 \mathrm{~V}, 300 \mathrm{~Hz}$

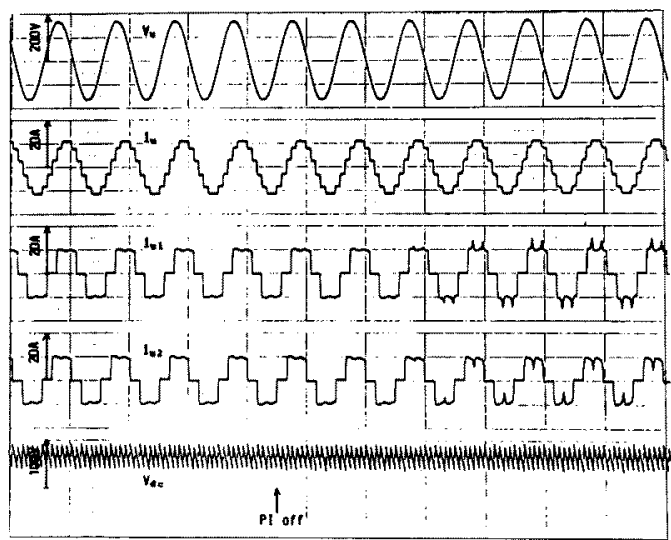

(b) $40 \mathrm{~V}, 300 \mathrm{~Hz}$

困 $13300 \mathrm{~Hz}$ の相間変圧器の実験結果

Fig. 13. Experimental results under $300 \mathrm{~Hz}$ interphase transformer.
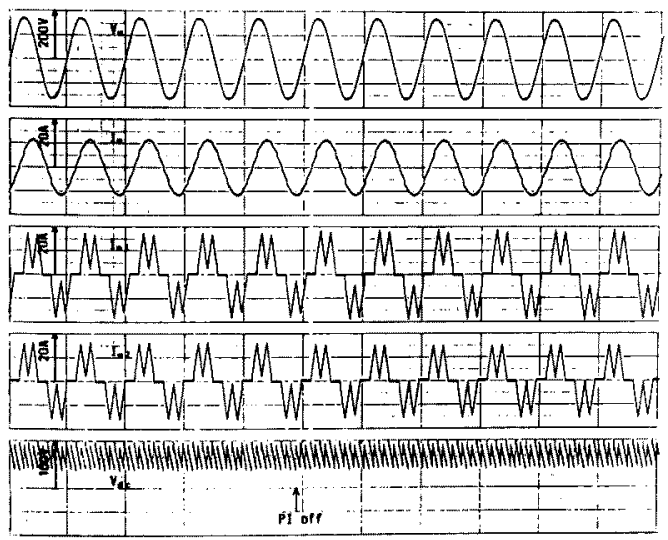

図 $14 L_{s}=2.4 \mathrm{mH}$ の実験結果

Fig. 14. Experimental result under $L_{s}=2.4 \mathrm{mH}$.

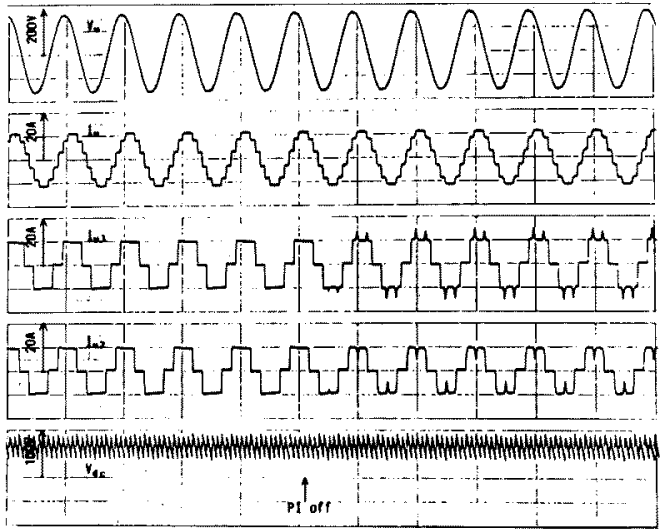

図 15 アルルアス変圧器の実験結果 Fig. 15. Experimental result in the case of using amorphous transformer. 
（a ）（b ）ともに鉄心が飽和し相間リアクトルが短絡 状態となるために $i_{u 1}, i_{u 2}$ にスパイク状の電流が流れ ている。

図 14 は, 図 $13($ a )で用いた変圧器に〈3・2〉節で述 ベたようにギャップを付加し，リアクトルとして用い た場合の応答波形である。それぞれの整流回路の入力 電流に 100\%近いリプルを生じているが，電流フィー ドバックの効果により出力電流がバランスし, 安定な 並列運転が行われている。また, 三相変圧器の一次側 電流 $i_{u}$ は正弦波に近い電流波形となっている。図 16 は，このときの $i_{u}$ の周波数スペクトラムを求めたも のである。高調波成分が大幅に減少しており，36パ ルス構成の整流回路と同等の入力電流が得られてい る。一方, 電流フィードバックを切離した後は, $i_{u 2}$ のリプル分が零付近にまで達して扔り, しかも平均值 で約 15\%程度のアンバランスを生じている。

図 15 㹥相間リアクトルにアモルファス変圧器を用 いた場合の実験結果である。アモルファス変圧器は, 透磁率が高く励磁電流が通常の変圧器に比べ $1 / 10$ 程 度である。このため鉄心が飽和しない状態では, 非常 に大きなインダクタンスとして働く。従って, 電流〉 イードバックにより整流回路の出力電流がバランスし た状態では, 入力電流にリプル分を全く生じていな い。図 17 はこのときの $i_{u}$ の周波数スペクトラムを求 めたものである。入力電流の第五，七次の高調波が消 去されており，理想的な 12 パルス構成の整流回路と なっている。

図 18 は実験に用いたアモルファス変圧器の $B-H$ 曲線である。一般に用いられているケイ素鋼板に比 べ, 鉄心の透磁率が大きく励磁電流が非常に少ないこ とがわかる。

〈4・3〉相間リアクトルの体積容量の比較 図 10 の $L_{s}=24 \mathrm{mH}$ の場合と図 13(a) の整流回路の入力電 流がバランスした状態を比較すると， $i_{d 1}, i_{d 2}$ の平均 值に対するリプル成分がほほ等しい大きさとなってい る。ここで，〈3・2〉節で述べた条件の下で図 13(a)で 用いた相間変圧器にギャップを付加すると約 $2.4 \mathrm{mH}$ のインダクタンスが得られる。従って, 電流フィード バックを付加しないでギャップを有する相間リアクト ルを用いた従来方式に比べ, 電流フィードバックを付 加しギャップのない相間変圧器を用いる本方式では, 相間リアクトルのインダクタンスを $1 / 10$ に低隇する ことができる。ここで，(13)式を(14)式に代入すれば 次式が得られる。

$$
L \fallingdotseq \frac{S B_{m} N}{I_{p}}
$$

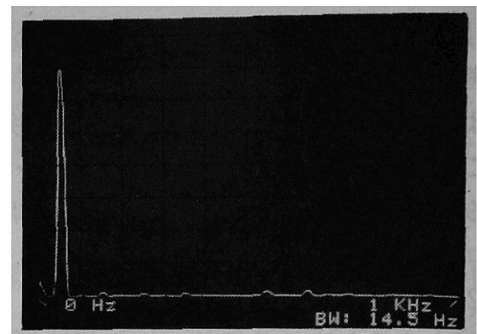

図 $16 L_{s}=2.4 \mathrm{mH}$ の場合の入力電流 スペクトラム

Fig. 16. Harmonic spectrum of the source current $i_{u}$ under $L_{s}=2.4 \mathrm{mH}$.

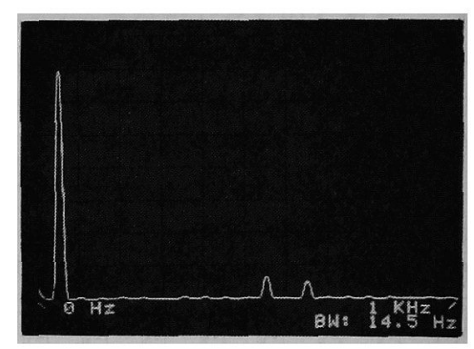

図 17 アモルファス変圧器の場合の入力 電流スペクトラム

Fig. 17. Harmonic spectrum of the source current $i_{u}$ in the case of under amorphous transformer.

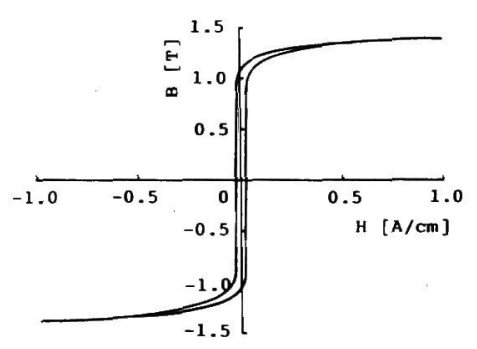

図 18 アモルファス変圧器の $B-H$ 曲線 Fig. 18. $B-H$ curve of amorphous transformer.

鉄心の飽和磁束密度を一定とするとインダクタンス は巻数に正比例する。つまり，電流フィードバックを 付加することで相間リアクトルの巻数を $1 / 10$ に減少 できる。簡単のために，鉄心の形状を円と仮定する と，磁路長は $1 / \sqrt{10}$ となる。すなわち，本方式によ り相間リアクトルの体積容量は; 約 $1 / 3$ に低減するこ 


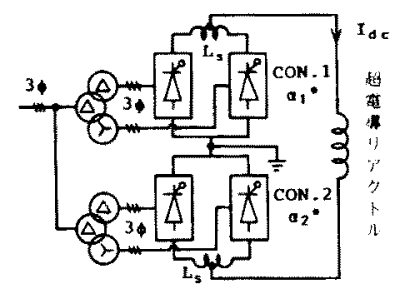

図 19 超電筫エネルギ一眝蔵システムの 電力変撸器

Fig. 19. Thyristor converter for superconducting magnetic energy storage systems.

とが可能となる。

〈4・4〉超電導エネルギー貯葴システムの電力变換 器超電導工ネルギー䠉蔵システムの電力変換器て は，直列に接続した 2 台の整流回路間の非対称制御に より有効電力と無効䉓力の同時制御方式が提案されて いるが(5)，入力電流の五，七次の高調波を完全に消去 することが不可能である。なおブリッジ内での非対 称制御も原理的には可能であるが，2組の転流の相互 影響により種々の問題が生じることが報告されてい $る^{(3)}$ 。このため, 有効・無効電力の同時制御と入力電 流の高調波の低減を目的とする非対称制御を行うため には，図19の回路構成が考えられるが、この詳細に ついては別の機会に報告したいと考えている。

\section{5.むすひ}

相間りアクトルを有する並列接続形サイリス整流 回路の電流バランスと相間リアクトルについて検討を 行った。得られた結論をまとめると以下のように なる(6)(7)。

（1）整流回路の制御角の䠣差が $1^{\circ}$ 以下と比較的 小さな場合でも各整流回路の出力電流がアンバランス となることを理諭的に明らかにした ${ }^{(6)}$ 。

(2) 侻来から用いられているギャップを有する大 形の相間りアクトルは整流回路の出力電流りプルのピ 一ク值の抑制が目的であり，平均倠を等しくするため には，何らかの対策が必要であることを明らかに Lた。

（3）電流フイードバックを付加することで良好な バランス特性が得られることを実験により確認した。

(4) 相間りアクトルにギャップのない $300 \mathrm{~Hz}$ 変圧器を用いることで相間りアクトルの小形・軽量化 （体積容量で約 1/3）が可能でることを実験により 明らかにした。

マイクロプロセッサが普及し電力変換器の制御回路
に広く用いられている現在では，整流回路の制御角の 誤差を低隇することが可能である。しかしながら，制 御回路の櫡成要素の一つである聥倍回路の分解能で決 定される顠差をなくすことはできない。ここでは， 制御角の僢差を $0.25^{\circ}$ としが，これは10ビット (1,024 违倍) の場合の最小誤美に相当する。従って, 本論文で検討した内容は，大容量の相間りアクトルを 有する並列接続形サイリス夕整流回路を設討するうえ で参考になるものと考える。

最後に, 本諭文㤌半薄体電力変換研究会で発表した 研究会資料(7)に加筆修正したものであることを付記 し，贵重な御討墖をいただいた各位にお礼申し上げま す。また，本研究を進めるにあたり御協力いただい た，東芝重電技術研究所八木沢猛氏に厚くお礼申し 上げます。

(平成元年1月 23 日受付, 同元年 6 月 27 日再受付)

$$
\text { 文献 }
$$

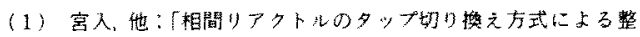

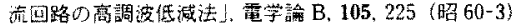

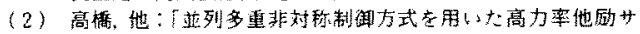

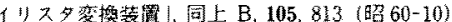

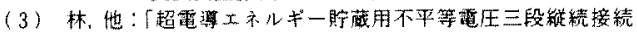

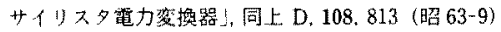

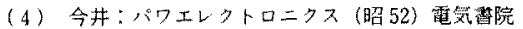

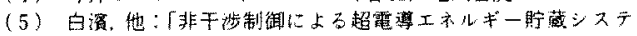

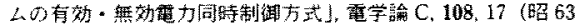
-1)

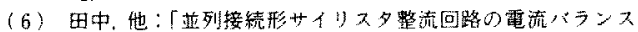

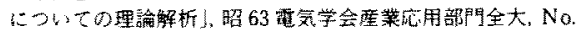
115

（7）田中，他：「亚列接繶形サイリス夕整流回路の電流バランス

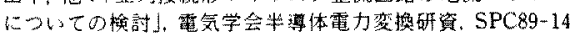
(平元)

\section{付 録}

\section{1.（7)式の導出}

図 3 に示した等価回路にお゙いて，CON.1について の回路方程式次式となる。

$$
\begin{aligned}
& e_{u 1}-l \frac{d i_{u 1}}{d t}=e_{v 1}-l \frac{d i_{v 1}}{d t} \ldots \ldots . . . \\
& e_{u 1}-e_{w 1}=l \frac{d i_{v 1}}{d t}+l \frac{d i_{d 1}}{d t}+e_{d 1} \\
& e_{u 1}-e_{w 1}=l \frac{d i_{u 1}}{d t}+l \frac{d i_{d 1}}{d t}+e_{w 1}
\end{aligned}
$$

$こ こ て ゙\left(\right.$ 付 2)，(付3)式に， $i_{a 1}=i_{u 1}+i_{v 1}$ を代入し整 理すれば次式を得る。

$$
e_{d 1}=\frac{1}{2}\left(e_{u 1}+e_{v 1}\right)-e_{w 1}-\frac{3}{2} l \frac{d i_{d 1}}{d t} \cdots \cdots \text { (付 4) }
$$

また, CON.2では

$$
e_{d 2}=e_{u 2}-e_{w 2}-2 l \frac{d i_{d 2}}{d t}
$$


となる。ここで, $I_{d}=i_{d 1}+i_{d 2}(=$ 一定) という仮定か ら次式を得る。

$$
\frac{d i_{d 1}}{d t}+\frac{d i_{d 2}}{d t}=0
$$

更に, 相間リアクトルの両端では常に次式が成立 する。

$$
2 L_{s} \frac{d i_{d 1}}{d t}=e_{d 1}-e_{d 2}
$$

従って, (付 6)式を(付5)式へ代入し, 更に(付 4), (付 5) 式および(1)〜（6)式を(付 7) 式に代入し整理 すれば次式を得る。

$$
\frac{d i_{d 1}}{d t}=\frac{\sqrt{6} E_{1}-\sqrt{8} E_{2}}{4 L_{s}+7 l} \cos \omega t
$$

(付 8)式を積分することで(7)式を得ることができ る。また，他のモードについても同様の方法により $\Delta i_{d 1}$ を求めることができる。

\section{2. 重なり角 $u_{1}$ の導出}

(付 8 ) 式から次式が得られる。

$$
\frac{d i_{u 1}}{d t}=\frac{\sqrt{6} E_{1}-\sqrt{8} E_{2}}{4 L_{s}+7 l} \cos \omega t-\frac{d i_{v_{1}}}{d t} \cdots \text { (付 9) }
$$

(付 1), (付 9)式から $i_{v 1}$ を消去すると次式となる。

$$
\frac{d i_{u 1}}{d t}=\frac{e_{u 1}-e_{v 1}}{2 l}-\frac{1}{2}-\frac{\sqrt{6} E_{1}-\sqrt{8} E_{2}}{4 L_{s}+7 l} \cos \omega t
$$

ここで, 重なり角 $u_{1}$ は $i_{u 1}\left(t_{1}\right)$ を初期值とし, $i_{u 1}\left(t_{2}\right)$ $=0$ となるまでの電気角を算出することで求められ る。従って, (付 10)式において, この二点の条件を 考慮して積分することにより $u_{1}$ を求めることができ る。

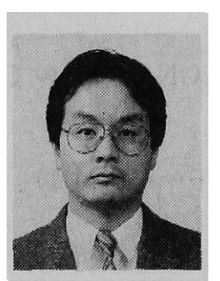

\section{田中俊 彦 (正員)}

昭和 34 年 7 月 29 日生。 59 年 3 月 長岡技術科学大学大学院工学研究科 修士課程修了。同年 4 月東洋電機製 造(株) 入社。60 年 7 月釧路工業高 等専門学校電気工学科助手。平成元年 4 月北海道職業
訓練短期大学校電子技術科教官, 現在に至る。主に, パワーエレクトロニクスに関する研究に従事。

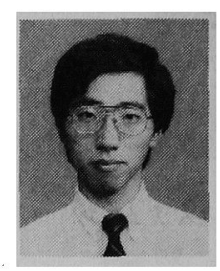

\section{小笠原悟司（正員）}

昭和 33 年 7 月 27 日生。 58 年 3 月長岡技術科学大学大学院修士課程 電気・電子システム工学専攻修了。 同年 4 月同大学工学部電気系助手, 現在に至る。主として，パワーエレクトロニクスに関 する研究に従事。計測自動制御学会, パワーエレクト ロニクス研究会, IEEE 会員。

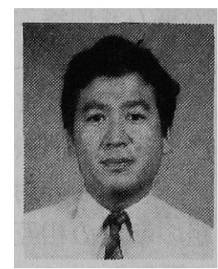

\section{赤 木 泰 文 (正員)}

昭和 26 年 8 月 19 日生。 54 年 3 月東京工業大学大学院電気工学尃攻 博士課程修了。同年 4 月長岡技術科 学工学部電気系助手, 59 年 10 月同 助教授。62 年 3 月 12 月 MIT 客員研究員。電動機 制御, 電力用能動フィルタ, 高周波インバータなどの 研究に従事。工学博士。55,58 年 IEEE/IAS Com. mittee Prize Power Award, 60 年電気学会論文賞受 賞。IEEE 会員。

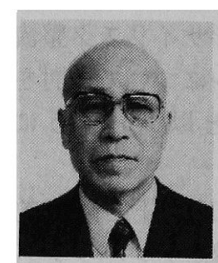

\section{難波江章（正員）}

大正 13 年 9 月 13 日生。昭和 22 年 9 月東京大学工学部電気工学科卒 業。26 年 9 月東京芝浦電気(株)入 社(現, 東芝)。 53 年 4 月長岡技術 科学大学教授, 現在に至る。主として回転機の高速制 御法やパワーエレクトロニクスとその応用システムに 関する開発研究に従事。工学博士。 55,58 年 IEEE/ IAS Committee Prize Power Award, 60 年電気学会 論文賞受賞。IEEE 会員。 